\title{
Evaluation of renewable energy development in power generation in Finland
}

Cite as: J. Renewable Sustainable Energy 5, 063132 (2013); https://doi.org/10.1063/1.4855095 Submitted: 22 July 2013 . Accepted: 10 December 2013 . Published Online: 20 December 2013

Alireza Aslani, Petri Helo, and Marja Naaranoja
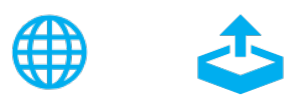

View Online

Export Citation

\section{ARTICLES YOU MAY BE INTERESTED IN}

Comparative analysis of energy security in the Nordic countries: The role of renewable energy resources in diversification

Journal of Renewable and Sustainable Energy 4, 062701 (2012); https: //

doi.org/10.1063/1.4765695

Influencing factors of private purchasing intentions of new energy vehicles in China Journal of Renewable and Sustainable Energy 5, 063133 (2013); https://

doi.org/10.1063/1.4850516

In search of the wind energy potential

Journal of Renewable and Sustainable Energy 9, 052301 (2017); https://

doi.org/10.1063/1.4999514

\section{AIP Author Services English Language Editing}




\title{
Evaluation of renewable energy development in power generation in Finland
}

\author{
Alireza Aslani, ${ }^{1,2, a)}$ Petri Helo, ${ }^{1}$ and Marja Naaranoja ${ }^{1}$ \\ ${ }^{1}$ Industrial Management Department, Faculty of Technology, University of Vaasa, \\ Vaasa 65101, Finland \\ ${ }^{2}$ Faculty of New Sciences and Technology, University of Tehran, Tehran, Iran
}

(Received 22 July 2013; accepted 10 December 2013; published online 20 December 2013)

\begin{abstract}
Renewable energy resources have historically played an important role for heat/electricity generation in Finland. Although diffusion costs of renewable energy utilization are higher than fossil fuels and nuclear power plants, other policy aspects and operation costs of renewables cover this gap particularly in high dependent countries to fossil fuels. The current paper discusses the role of renewable portfolio in the Finland's energy action plan during 2011-2020. A system dynamics model is constructed to evaluate different costs of renewable energy utilization by 2020. Results show that total costs of new capacities of renewable energy systems as well as operation and maintenance costs of current systems bring $7 \%$ saving compared to total costs of new natural gas power plants (as a sample for second scenario) in Finland. (C) 2013 AIP Publishing LLC.
\end{abstract} [http://dx.doi.org/10.1063/1.4855095]

\section{INTRODUCTION}

Energy security concerns along with consumption growth are rapidly rising in importance in almost all countries in particular high dependence countries to imported fossil fuels such as Finland. In response, renewable energy resources (RER) are a solution to reduce dependency on imported energy and provide social and environmental benefits. To decrease the dependency and improve security of energy supply, utilization of RER has been debated by Finnish governments and policy makers. However, speed of new RE development plans particularly wind power has lagged that of other European countries in recent years in Finland. Compared to 27 European countries, Finland had almost low capacities of wind power (19/27), solar power (17/27), and solar heating (23/27) in 2010.

To succeed diffusion programs of renewable energy(RE) development, different strategies such as technological improvements, increased economies of scale, and strong policy support should be contributed in both developed and developing countries. ${ }^{1}$ Nevertheless, compared to traditional energy sources, promotion of electricity/heat generated by RER is limited because of its relative investment high costs.

This study compares the costs of RE development and fossil fuels according to the Finnish energy action plan for electricity/heat generation by 2020 . Due to the complexity of such studies, as well as different factors effects on costs analysis, the system dynamics approach is implemented to analyze the effectiveness of RE policies.

The work is organized based on the following sections: Energy structure, supply, and consumption in Finland are reviewed in Sec. II. In Sec. III, the role of RE utilization in Finland is discussed. Indeed, important RERs and their potentials are also reviewed. Related polices and government's schemes to RE utilization in Finland are described in Sec. IV. Different parts of RE and fossil fuels system's costs in Finland are reviewed in Sec. V. Finally, a system dynamics model for cost analysis of RE utilization during 2011-2020 is proposed in Sec. VI.

\footnotetext{
${ }^{\text {a) }}$ Author to whom correspondence should be addressed. Electronic mail: alireza.aslani@uva.fi. Tel.: +358-442550010.
} 

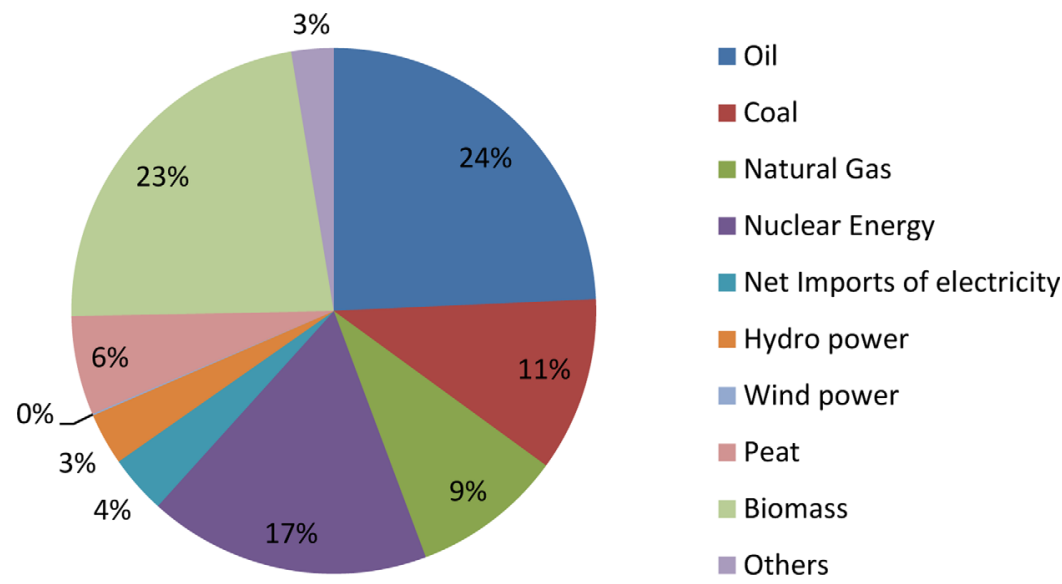

FIG. 1. Share of each energy source in total energy consumption in Finland in 2011.

\section{ENERGY STRUCTURE IN FINLAND}

Finland is one of the northernmost countries in Europe with a population of 5429894 ( $0.72 \%$ of Europe $){ }^{2}$ The country is one of the developed countries from economic and social welfare indicators. It is also one of the most energy intensive countries because of a cold climate, its energy intensive industries, wide sparsely populated areas with long distances, and a high standard of living. ${ }^{3}$ In 2011, the total energy consumption in Finland was 1392279 TJ with $52 \mathrm{Mt} \mathrm{CO}_{2}$ Emissions. ${ }^{4}$ Figure 1 illustrates the primary energy consumption in Finland by sources in 2011. As figure shows, the share of fossil fuels and RERs were around $44 \%$ and $28 \%$ in 2011.

Due to the Finland's cold climate, electricity and district heating systems have key roles in residential and industrial sectors. In 2011, the share of Finnish industries in electricity consumption was about $48.7 \%$ of total electricity consumption. Figure 2 shows the end use of energy in different Finnish sectors with special focus on main Finnish industries in $2011 .^{4}$ While total electricity consumption in Finland was about $84241 \mathrm{GWh}$, industrial sector consumed more than $41000 \mathrm{GWh}$ of this consumption. While forest and paper, metal and chemical, and engineering industries represent $80 \%$ of Finnish industrial products and services, the forest and paper industry alone consumes more than $50 \%$ of electricity of the industrial sector (20858 GWh) ( $25 \%$ of total energy consumption).

In 2011, the electricity generation by mode of sources was $22.3 \mathrm{TWh}$ for nuclear power, 12.3 TWh for hydropower, 14.2 TWh for coal and peat, 9.2 TWh for natural gas, $1 \mathrm{TWh}$ for oil

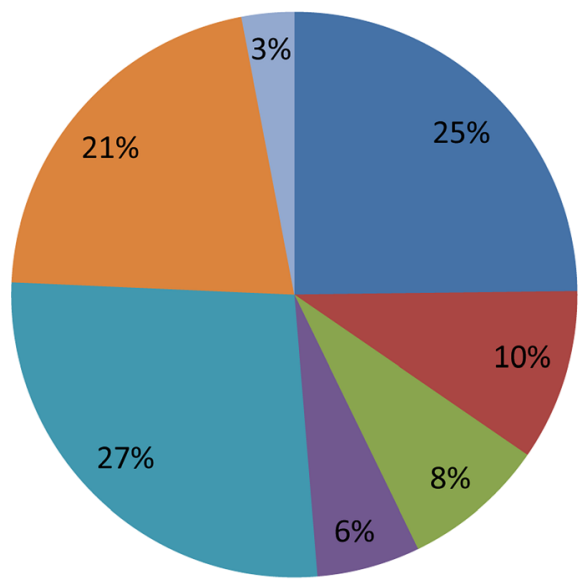

- Forest Industy

Metal Indistry

- Chemical Industry

- Other Industries

HOUSEHOLDS AND

AGRICULTURE

- SERVICES AND PUBLIC CONCUMPTION

FIG. 2. End use of energy in different Finnish sectors in 2011. 
and other fossil fuels, 10.1 TWh for wood fuels, 0.5 TWh for wind power, and 0.4 TWh for other renewable sources. ${ }^{4}$ The combined heat and power (CHP) plants have around $43 \%$ of the electricity/heat generation in Finland categorized in two groups of industry (17.7\%) and district heat $(26.1 \%) .{ }^{4}$ About 13.9 TWh of electricity also was imported based on different agreements with neighbor's countries in 2011 (e.g., Nordpool).

\section{RENEWABLE ENERGY UTILIZATION IN FINLAND}

RERs in particular biomass has important role in the primary energy supply of Finnish strategies. According to the Finland's national action plan for electricity/heat generation from RERs, the share of RE should be increased to $38 \%$ of the gross final consumption by $2020 .{ }^{5}$ For instance, while the share of wind power among other RE alternatives was less than $1 \%$ of the total RE supply in 2009 , it should be increased to $15 \%$ by 2020 . Table I shows the amount (TWh) and share of RERs in total energy consumption in some years. ${ }^{4}$

The principal RE source in Finland is Biomass that makes about $86 \%$ of the total RE utilization. The availability of biomass resources is distributed in 15 areas in Finland. Some examples of bioenergy are firewood, bark, sawdust, forest chips, demolition wood, pellets, and briquettes. About $70 \%$ of the bioenergy was produced by the forest industry in Finland in $2010 .^{6}$ The country is the third with highest capacity of biomass power generation in European Union (EU) after Germany and Sweden. ${ }^{7}$ The major uses are in the industries particularly paper and wood industry.

Hydropower is the second largest RER utilization in Finland. In 2011, 205 hydropower plants generated $12.3 \mathrm{TWh}$ electricity that had a share of $11.2 \%$ among RERs in Finland. Approximately $90 \%$ of electricity generated by hydropower comes from large-scale hydropower. ${ }^{8}$ This source has little potential for development as most of the possibilities for growth have been already used. However, small-scale hydropower is important for local development that receives government's supports. According to the Finnish policies (National Climate and Energy Strategy), small-scale hydropower plants $(<1 \mathrm{MW})$ can benefit through the energy tax exemption. The capacities over $1 \mathrm{MW}$ do not receive any electricity production support in Finland. ${ }^{8}$

The utilization of wind power is the fastest growing among other RERs in Finland. ${ }^{9}$ Wind power has also the highest average annual installed capacity in Europe (around $11.5 \mathrm{GW}$ per year) that should be increased to $14 \mathrm{GW}$ by 2020 . Although this source was carried out for the first time in 1992 in Finland, the electricity generated by wind power should be rise to 6 TWh by $2020 .^{10}$

In 2009, solar photovoltaic modules produced $5 \mathrm{GWh}$ of electricity in Finland (mostly in universities and research centers). ${ }^{3}$ Diffusion challenges of solar energy utilization in Finland are categorized in three terms: Geographical feasibility, commercial, and technical. Because of Finland's geographical location, the solar radiation is not noticeable compared to some European countries such as Germany, France, and Italy. However, due to the long daylight hours in the summer months (more than $20 \mathrm{~h}$ ), some regions such as Ostrobothnia (Coast's West) have good potential for solar development in Finland. ${ }^{9}$

Finally, the classical forms of geothermal energy (hot and dry rock or steam) are not economically feasible for utilization in Finland. Thereby, this source is restricted to utilization of

TABLE I. Amount and share of renewable energy resources in total energy consumption in Finland.

\begin{tabular}{lcc}
\hline \hline & TWh & Share \% \\
\hline 1991 & 57.6 & 18.4 \\
1996 & 71.5 & 20.5 \\
2001 & 87.3 & 22.9 \\
2006 & 101.8 & 24.5 \\
2011 & 109.3 & 28.3 \\
\hline \hline
\end{tabular}




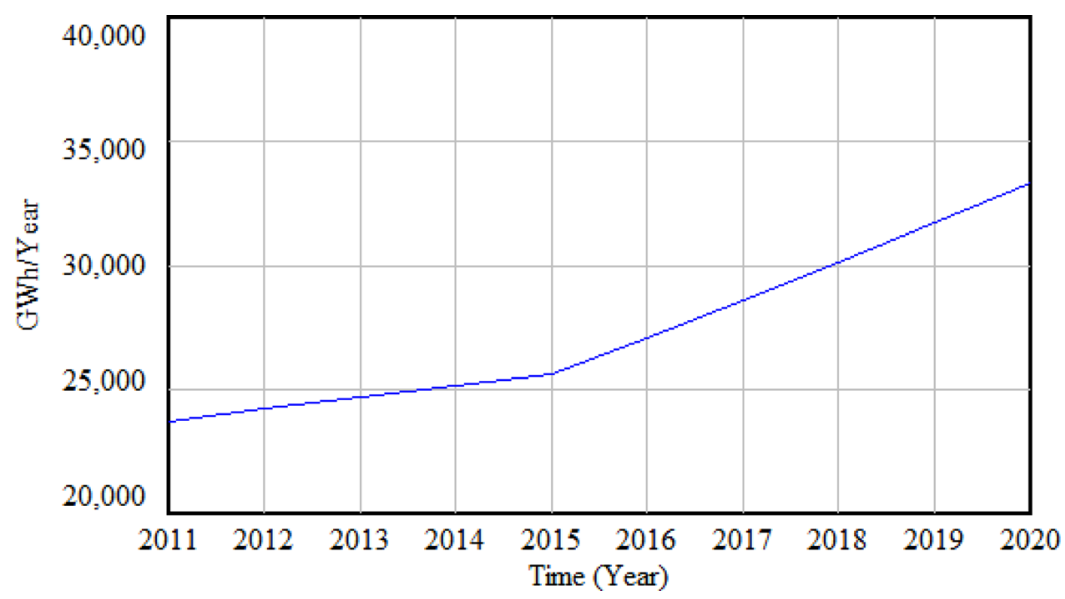

FIG. 3. Electricity/heat generated by RERs based on Finnish Action plan (GWh/year).

ground-heat with heat pumps. In Finland, heat pumps are mainly used for space and hot water heating in single-family houses from boreholes, surface sediments, lakes, and rivers. In 2011, 3.5 TWh energy produced by heat pumps with $13.6 \%$ growth compared to $2010{ }^{4}$

\section{POLICIES RELATED TO RENEWABLE ENERGY DEVELOPMENT}

According to the studies and based on the Finnish energy action plan, the amount of electricity/heat consumption in Finland will be changed from $265959 \mathrm{GWh}$ in 2012 to $285177 \mathrm{GWh}$ by 2020 (7.2\% growth). ${ }^{11}$ Meanwhile, the amount of energy contributed from RERs should be rise to $33420 \mathrm{GWh}$ (Figure 3).

The process of RE development in Finland is described in different layers. ${ }^{3}$ The layers have strategic, policy, and practical targets that provide a portfolio of political, technological, managerial, social, and cultural schemes (Figure 4). Table II summarizes each layer and their related schemes. ${ }^{3}$

\section{COSTS OF RENEWABLE ENERGY UTILIZATION}

Investment is a key point for diffusion of RE technologies. Specifically, to utilization of RERs economically reasonable, they should be adopted pervasively by supports of the government and contributions of the private sector. Research show that financial measurement that indicates the required investment and other costs of RE utilization (e.g., maintenance and operation), as well as efficiency of each energy source (performance) are two key criteria for RE promotion. ${ }^{1}$ For instance, today wind energy is cost-competitive in many increasing cases and is being developed even in the absence of any government support. While efficiency and reliability of the wind turbines have increased, the capital costs have been halved over the last 30 years. ${ }^{26}$ On the other hand, the cost of solar photovoltaic (PV) technologies is being fall quickly as demand is rising with costs declining by $19 \%$ with each doubling of global capacity. ${ }^{25}$ Following each criteria and their amount to electricity/heat generation by RER are reviewed.

\section{A. Energy conversion efficiency of energy sources in Finland}

Efficiency has various definitions in different sciences. One of the definitions of energy efficiency is related to energy conversion efficiency $(\eta)$ that means using less energy to provide the same or improved desirable output. In a wider definition, the efficiency of electricity/heat generation is mixed with annual exploitability index to show the performance of energy sources. ${ }^{12}$

Two main fossil sources for electricity generation in Finland are coal/peat, and natural gas. While the share of coal/peat in electricity generation by fossil fuels was $61 \%$, natural gas had a 


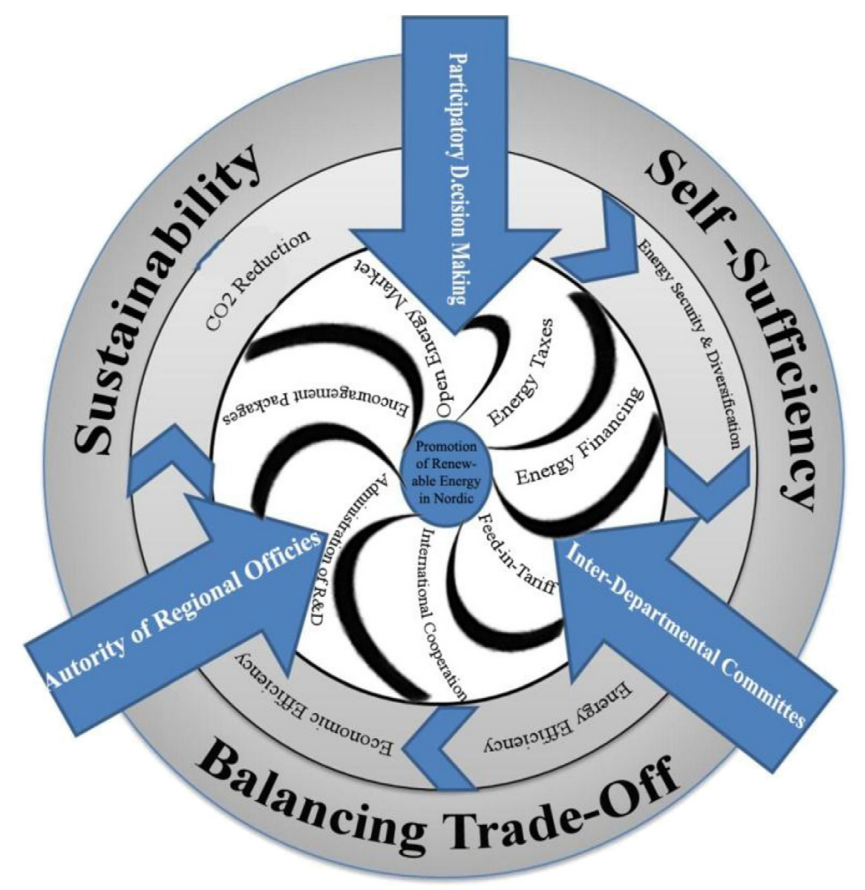

FIG. 4. Layers of RE development in Finland.

share of $37 \%$ in $2011 .{ }^{29}$ However, the natural gas has many advantages compared to coal. For instance, natural gas burns more cleanly than coal and other fossil fuels. It is also more efficient compared to coal/peat. ${ }^{30}$

According to the report of the US Energy Information Administration (2013), the capital cost of the natural gas power plants is almost a quarter of the capital cost of coal/peat power plants. ${ }^{31}$ Natural gas can be easily transported via pipelines. Even though the natural gas is cleaner than coal and oil, it still contributes a large amount of carbon. From supply viewpoint, Finland has $100 \%$ dependency to imports of this source. ${ }^{32}$

The costs of RE utilization and development (first scenario) in this article are compared with natural gas as a replacement fossil fuel (second scenario). The reason is because of the role of greenhouse gas reduction in the Finland's national action plans. In other words, to launch the system dynamics model of RE cost analysis, the researchers assume that the new capacities of fossil source for electricity/heat generation are natural gas power plants.

Indeed, the main objective of the current article is to present and implement a system dynamics model for cost analysis in renewable energy industry. Therefore, natural gas is a scenario for system dynamics model and the presented model can be updated with new scenarios such as nuclear power plants.

The main biomass source in Finland is wood used in the CHP plants. Wood residual chips (forest chips) are the cheapest available wood fuel and used as mixture with milled peat. ${ }^{3}$ As the costs of generated electricity by wood are clearly higher than other sources, there are not any power plants for just electricity generation by wood in Finland. CHP plants in Finland are working with a maximum power output capacity of $30 \mathrm{MW} .{ }^{17}$ If the CHP plants are used for electricity/heat generation, the investment cost of a merely electricity producing power plant are around $3000 € / \mathrm{kW}$ with efficiency around $35 \%$.

On the other hand, statistics show that the average peak load utilization of wind power plants time was $1789 \mathrm{~h}$ per year in the year $2006 .{ }^{13}$ In this study, a peak load utilization time of $2000 \mathrm{~h}$ per year with $40 \%$ energy conversion efficiency is estimated for biomass power plants. A lifetime of 25 years is also used for wind turbines. Finally, the energy conversion efficiency of $60 \%$ for hydropower, $20 \%$ for solar PV and thermal, and $20 \%$ for heat pumps are estimated to electricity/heat generation. ${ }^{14}$ 
TABLE II. Different layers of strategic analysis of diffusion of renewable energy in Finland and the Nordic countries.

\begin{tabular}{|c|c|c|c|}
\hline Layer & Description & Sub-layer & Aim \\
\hline \multirow[t]{3}{*}{ Dimensions } & \multirow[t]{3}{*}{$\begin{array}{l}\text { To show the purposes of diffusion } \\
\text { of RE utilization }\end{array}$} & Self-sufficiency & $\begin{array}{l}\text { To reduce consumption of fossil fuels } \\
\text { and increase the dependency of } \\
\text { indigenous resources }\end{array}$ \\
\hline & & Balancing trade-off & $\begin{array}{l}\text { To help to economic and technologic } \\
\text { growth of the regions }\end{array}$ \\
\hline & & Sustainability & $\begin{array}{l}\text { To reduce pollution and } \\
\text { environmental impacts }\end{array}$ \\
\hline \multirow[t]{3}{*}{ Characters } & \multirow{3}{*}{$\begin{array}{l}\text { To identify main stakeholders } \\
\text { affect public policies and process } \\
\text { of decision-making }\end{array}$} & $\begin{array}{l}\text { Participatory decision- } \\
\text { making }\end{array}$ & $\begin{array}{l}\text { To have the supports of the } \\
\text { community organizations and citizens }\end{array}$ \\
\hline & & $\begin{array}{l}\text { Inter-departmental } \\
\text { committees }\end{array}$ & $\begin{array}{l}\text { To have a comprehensive and } \\
\text { coordinative decision making }\end{array}$ \\
\hline & & $\begin{array}{l}\text { Authority of regional } \\
\text { offices }\end{array}$ & $\begin{array}{l}\text { To increase the role of regional s } \\
\text { (municipalities) in decision-making }\end{array}$ \\
\hline \multirow[t]{4}{*}{ Objectives } & \multirow[t]{4}{*}{$\begin{array}{l}\text { To show different perspectives of } \\
\text { diffusion of RE }\end{array}$} & $\begin{array}{l}\text { Energy security and } \\
\text { diversification }\end{array}$ & $\begin{array}{l}\text { To reduce the dependency to the } \\
\text { external resources (energy imports) }\end{array}$ \\
\hline & & Energy efficiency & $\begin{array}{l}\text { To produce specific amount of } \\
\text { services using less energy }\end{array}$ \\
\hline & & Economic efficiency & $\begin{array}{l}\text { - Technical efficiency } \\
\text { - Allocative efficiency }\end{array}$ \\
\hline & & $\mathrm{CO}_{2}$ reduction & $\begin{array}{l}\text { To minimize } \mathrm{CO}_{2} \text { emissions from } \\
\text { fossil fuel burning caused by human } \\
\text { activities }\end{array}$ \\
\hline \multirow[t]{7}{*}{ Key schemes } & \multirow[t]{7}{*}{$\begin{array}{l}\text { To describe different policies or } \\
\text { regulations related to diffusion of } \\
\text { RERs utilization }\end{array}$} & Energy financing & $\begin{array}{l}\text { To direct government investment on } \\
\text { the RE technologies and efficiency } \\
\text { solutions }\end{array}$ \\
\hline & & Energy taxes & $\begin{array}{l}\text { To curb the growth of energy } \\
\text { consumption }\end{array}$ \\
\hline & & Open energy market & To make RE utilization competitive \\
\hline & & $\begin{array}{l}\text { Encouragement packages } \\
\text { and green certificates }\end{array}$ & $\begin{array}{l}\text { To improve the knowledge and } \\
\text { awareness of the citizens about RERs }\end{array}$ \\
\hline & & Administration of research & To manage research and $R \& D$ funds \\
\hline & & International cooperation & To share and crate the knowledge \\
\hline & & Feed-in-tariff & $\begin{array}{l}\text { To accelerate investment in RE } \\
\text { utilization }\end{array}$ \\
\hline
\end{tabular}

\section{B. Cost data of renewable energy utilization}

The costs of energy sources utilization to electricity/heat generation are categorized in the four main items including initial investment (cost of capital), operations and maintenance costs $(\mathrm{O} \& \mathrm{M})$, cost of fuel, and costs of greenhouse gases (e.g., carbon emissions). Selling price, taxes, and subsides are not included in the costs discussed in this study. Beyond the effects of technology development on prices decreasing in RE technologies, the overall price level of RE systems has remarkably risen in recent years (because of construction prices such as metals and other materials used in the power plant components and fuel prices).

To increase the validity of current article and provide a similar scale implementable for other countries or cases, costs of renewable energy utilization calculated by the US department of energy are used in this study (except fuel cost and emission cost). That reference is the most valid and reliable source of energy costs analysis. ${ }^{15}$ However, data would be different according to different calculations and references and the years. While the investment costs are based on the estimations until 2017, value added costs such as taxes are not included in the study. Indeed, we assume that new combined cycle gas turbine plants are located near the existing natural gas network in Finland, if the policy makers want to develop electricity generation via 
fossil fuels. Therefore, the connection fee does not contribute in the investment cost. The investment cost of the combined cycle gas turbine plant is estimated $26.8 € / \mathrm{MWh}$. The O\&M costs also is proposed 3.1 $€ / M W h$. As the prices of fossil fuels have recently risen, the natural gas prices are assumed 40.5 €/MWh. According to the EU regulations, an additional cost for fossil fuels should be also added as greenhouse gas emission price. The emission price is estimated $60 € /$ tonCO $\mathrm{C}_{2}$ for period 2013-2020. ${ }^{17}$ According to the statistics, the "life cycle analysis" of $\mathrm{CO}_{2}$ emissions for natural gas to electricity generation is about $469 \mathrm{gCO}_{2} / \mathrm{kWh}^{16}$ The electricity production costs has been calculated with emission prices of $60 € /$ ton $\mathrm{CO}_{2}$ in this study.

For RERs, the investment cost of a wood power plant is assumed 43.7 $€ / M W h$. The fuel prices are also estimated as peat $8.90 € / \mathrm{MWh}$ and wood chips $13.4 € / \mathrm{MWh}$. The O\&M costs is also estimated 10.6 $€ / M W h$. The level of investment in wind power plants (on-shore) is estimated around 64.1 €/MWh. However, the investment cost level depends on the market volume, competition situation, project size, and regional conditions. ${ }^{17}$ Based on the operation experience of existing wind power plants, the O\&M costs of wind power plants is estimated 7.5 $€ / \mathrm{MWh}$ in Finland, in which the bigger units size decrease the O\&M costs.

In 2009, the average cost of installed solar panels systems was $5.8 € / \mathrm{W}$ installed capacity in Germany, $\$ 3.5 € / \mathrm{W}$ in Japan, and ranging from $3.8-8 € / \mathrm{W}$ in the United States. ${ }^{18,25}$ Therefore, $2 \mathrm{~kW}$ capacity solar panel system would cost between $7100 €$ and $15000 €$ installed depending on the location. About $20 \%$ additional costs should also be added to the named costs (e.g., batteries).However, the prices of solar technologies dropped by 50\% in 2011 due to adoption of new technologies in related industries. ${ }^{19}$ In this study, the investment price and O\&M cost are assumed $130 € / \mathrm{MWh}$ and $6.7 € / \mathrm{MWh}$ in Finland.

The cost of installing a heat pump using ground-heat is about twice the price of installing systems based on electricity. However, the running costs of ground-heat systems are much lower. ${ }^{20}$ Thereby, the investment and O\&M costs of this technology are estimated 58.9 €/MWh and 7.4 €/MWh in Finland. Finally, the investment and O\&M costs of electricity generated by hydropower are approximately estimated 59.2 €/MWh and 3.1€/MWh.

\section{SYSTEM DYNAMIC MODEL}

System dynamics is a methodology based on system thinking to understand and model the behavior and activities of the complex systems over time..$^{21,22}$ The methodology is based on the feedback structure, meaning that decisions with specific goals alter the world and subsequently lead to new decisions. ${ }^{23}$ The process of system dynamics analysis is comprised of six steps, which are (1) system understanding, (2) problem identification and definition, (3) system conceptualization, (4) simulation and validation, (5) policy/decision analyzing and improvement, and (6) policy/decision implementation. As Figure 5 illustrates, the main concentration of system dynamics is "understands the system," and all steps try to have feedbacks for system understanding. In addition, causal interactions of all main variables in a system are represented in the system dynamics as a causal loop diagram.

Through a review of existing literature among over 2000 pages of documents and articles including annual reports, detailed government, project reports, and published investigations, we have assessed the Finnish energy sector to (1) define the main problems and objectives of renewable energy utilization and (2) identify the key variables and policies. Through a review of existing literature, we investigated the causal relationships pertaining to dependency and renewable energy utilization. Then, the causal relationships are qualitatively examined. Indeed, the causal relationships between variables and formulating relationships are quantitatively examined via collecting relevant data. The integrated stock-flow diagram is developed to simulate and compare scenarios.

\section{A. Conceptualization of renewable energy development in Finland}

The causal loop diagram is to qualitatively visualize, understand, and analyze the system. The diagram consists of nodes (variables) and their relationships (arrows). Relationship of two variables can be positive or negative. ${ }^{24}$ For quantitative analysis, the causal loop diagram is transformed to 


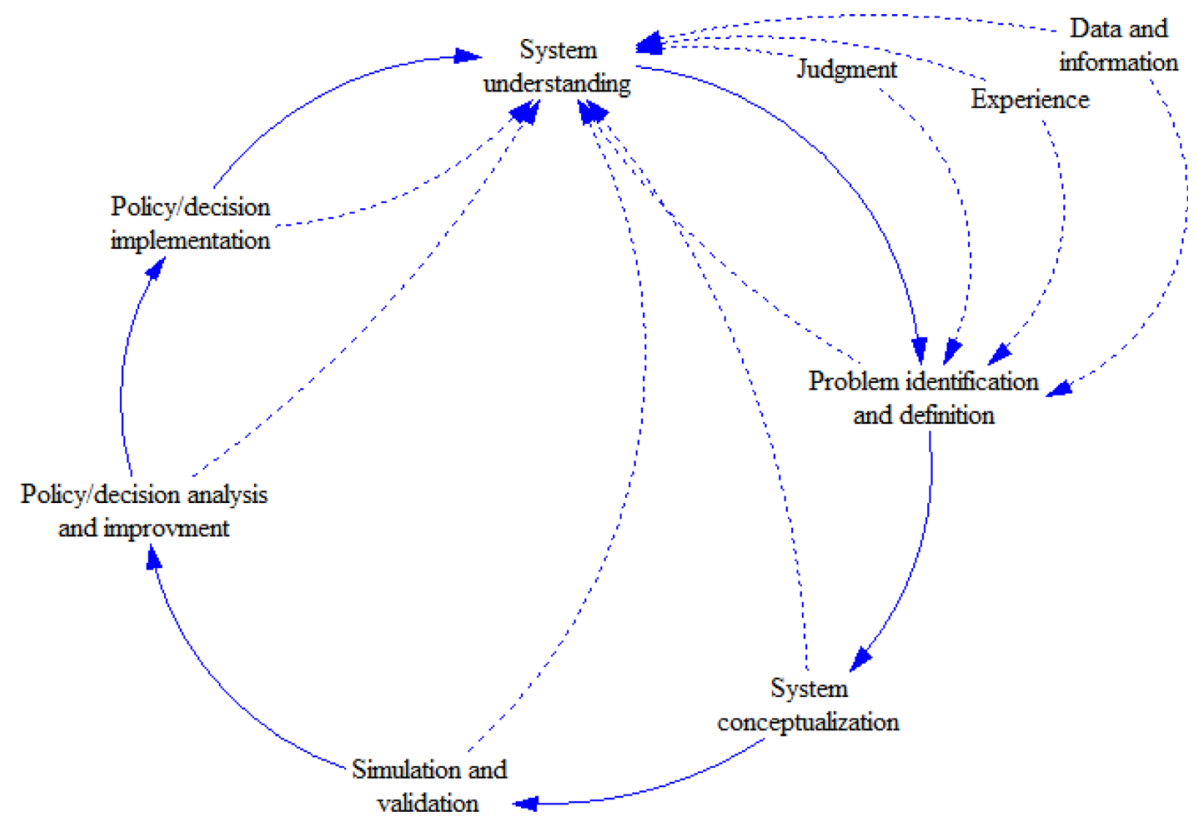

FIG. 5. Process of system dynamic analysis.

a stock and flow diagram. This diagram and stock-flow diagram play central role in system dynamics modeling. Figure 6 shows the inter-relations of the influencing factors in the frame of causal loop diagram. Among a number of variables within the subsystems of renewable energy development, only main variables that are related to our model are included in the figure.

Growth in energy and electricity demand positively affects dependency on fossil fuels system. Increasing dependency to fossil fuels means Finland will be more dependent to energy imports that bring risks and uncertainties. In response, government tries to overcome to dependency by introducing several policies such as development of RE utilization. ${ }^{21} \mathrm{RE}$ development policies consist different strategies including polices related to technology development and encouragement packages. By developing technologies, the costs of renewable energy utilization including construction, operation, and maintenance (O\&M) decrease. Therefore, the capacity of

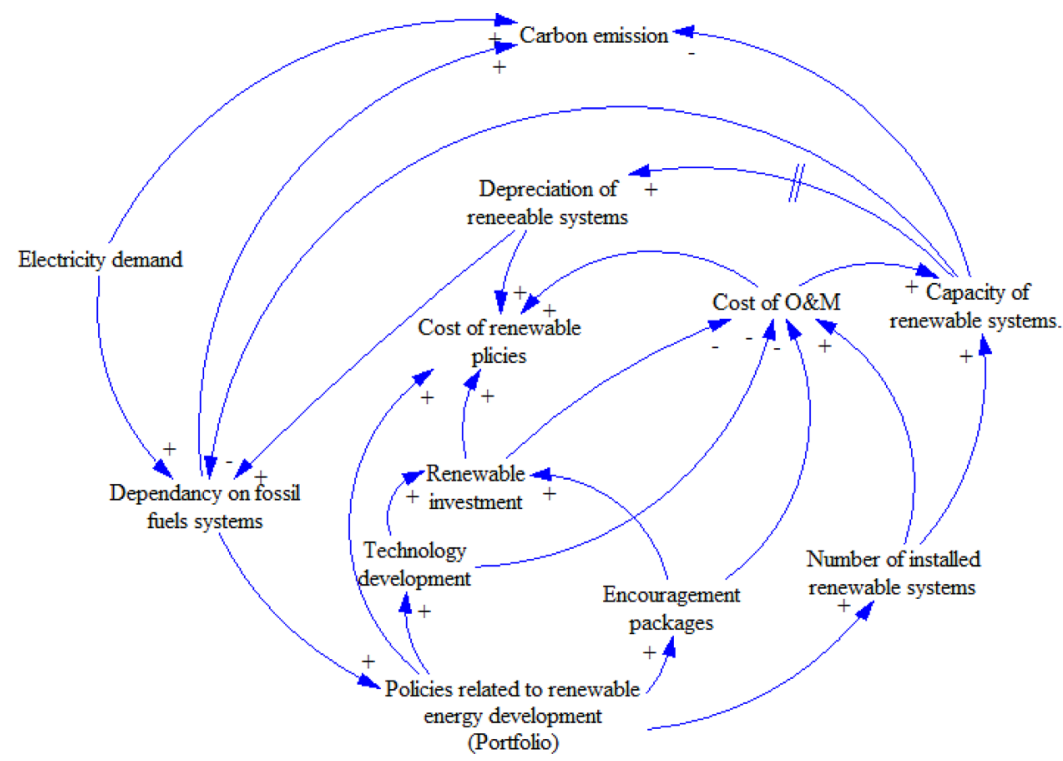

FIG. 6. Causal loop diagram of the renewable energy development. 
RE systems increase. This not only decreases the energy dependency on external sources, it also negatively influence on carbon emission. On the other hand, the depreciation period of a renewable system affect dependency (increase) after a period (e.g., 20 years for wind power plants). It also affects costs of renewable policies (increase).

\section{B. Dynamic analysis of renewable energy utilization plans}

Based on the above causal loop variables, a system dynamics model is constructed to evaluate and compare effects of RERs on Finnish energy dependency during 2011-2020. To develop the quantitative model, we collect data about Finnish energy and renewables from the Statistics Finland, Finnish Ministry of Employment and the Economy Reports, and US Department of Energy. According to Finland's national action plan for promoting RE (document number: 2009/28/EC), Finland should have 77 TWh electricity/heat utilized by RERs by $2020 .^{4,5,10}$ To achieve the targets, different promotional schemes have been introduced. Table III reviews some of the important policies and targets for RE development in Finland by 2020.

There are five stocks in the proposed system dynamics model including, capacity of biomass electricity/heat, capacity of hydropower electricity, capacity of solar electricity/heat, capacity of wind power electricity, and capacity of geothermal electricity/heat. Total amount of electricity/ heat generated by renewable resources is the sum of capacity of each RER. Figure 7 shows the system dynamics model of RE development in Finland. As figure illustrates, the capacity of each RER influenced by current systems plus new installations (based on the policies and plans) and decreased number of RER systems affected by delay time (depreciation). We assume that the depreciation periods of RER systems are 20 years for solar, 25 years for wind, 25 years for geothermal, 30 years for biomass plants, and 15 years for small hydropower. The number of increased RER systems (rates in the system dynamics model) is dirrectly affected by plans and government policies discussed in Sec. II and Table III. As disscused in Sec. V, the costs data(investment and O\&M costs) are bsed on the data published by the US Department of Energy. ${ }^{15}$ Figure 8 shows the total costs of electricity/heat generated by RERs during 2011-2020. These costs include current RE systems (O\&M costs) and new installations during 2011-2020.

TABLE III. Overview some of the Finland's targets and policies to promote RE utilization. ${ }^{10}$

\begin{tabular}{|c|c|c|}
\hline Renewable resource & Target in 2020 & Some policy schemes \\
\hline Biomass-wood & $\begin{array}{l}\text {-Increasing the use of wood chips in CHP } \\
\text { production and separate heat production to } \\
25 \mathrm{TWh} \text { per year by } 2020 \text { (equivalent to } \\
13.5 \times 10^{6} \mathrm{~m}^{3} \text { of wood chips) }\end{array}$ & $\begin{array}{l}\text {-Support package comprises energy support } \\
\text { for small-sized wood, } \\
\text {-Feed-in tariff to compensate for the } \\
\text { difference in costs } \\
\text { between wood chips and alternative fuels, } \\
\text {-Feed-in tariff for small CHP plants, }\end{array}$ \\
\hline $\begin{array}{l}\text { Biomass- Small-scale } \\
\text { use of wood }\end{array}$ & $\begin{array}{l}\text {-Maintaining the small-scale use of wood for } \\
\text { heating purposes at its present level of } \\
12 \mathrm{TWh} \text {, }\end{array}$ & $\begin{array}{l}\text {-Electricity tariffs which vary hour by hour } \\
\text { (Incentives to use wood as a source of extra } \\
\text { heating) }\end{array}$ \\
\hline Biomass-biogas & $\begin{array}{l}\text {-Use of biogas should be increased to } 0.7 \mathrm{TWh} \\
\text { by } 2020 \text {, }\end{array}$ & -Market-based feed-in tariff scheme \\
\hline Pellets & -Target for use of pellets is $2 \mathrm{TWh}$ in 2020 & $\begin{array}{l}\text {-Investments related to the use of pellets in } \\
\text { renovated buildings will be subsidized with } \\
\text { investment grants }\end{array}$ \\
\hline Hydropower & $\begin{array}{l}\text {-Increasing around } 0.5 \mathrm{TWh} \text { per year of } \\
\text { average water flow to } 14 \mathrm{TWh} \text { in } 2020\end{array}$ & $\begin{array}{l}\text {-Small hydropower is promoted by means of } \\
\text { the existing investment support scheme }\end{array}$ \\
\hline Wind power & $\begin{array}{l}\text {-Wind power production will rise to } 6 \mathrm{TWh} \text { by } \\
2020\end{array}$ & $\begin{array}{l}\text {-Market-based feed-in tariff scheme funded } \\
\text { from the State budget }\end{array}$ \\
\hline Heat pumps & -Increasing to 8 TWh by 2020 & $\begin{array}{l}\text {-Heat pumps in renovated buildings will be } \\
\text { subsidized with investment grants }\end{array}$ \\
\hline Solar & -Increase to $10 \mathrm{MW}$ by 2020 & $\begin{array}{l}\text {-For one-family houses, solar heating systems } \\
\text { are promoted through the tax system by } \\
\text { granting an offset for the household }\end{array}$ \\
\hline
\end{tabular}




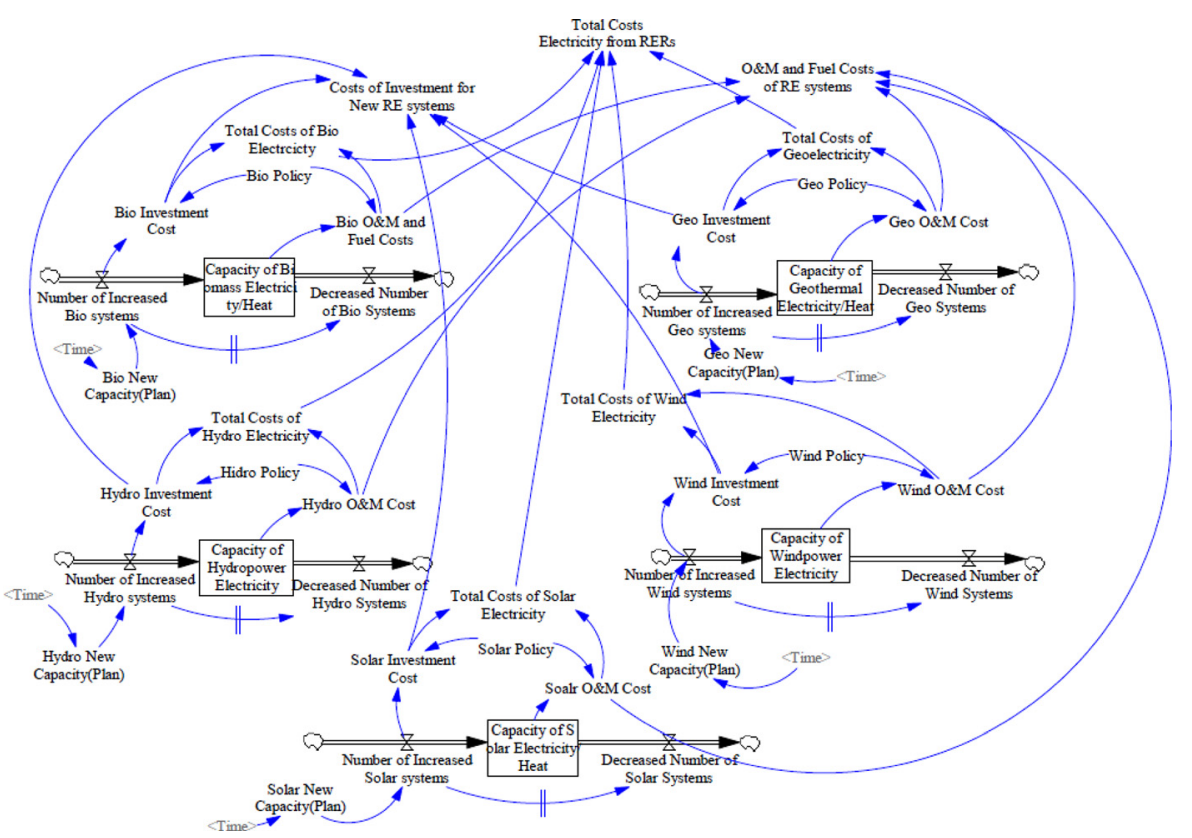

FIG. 7. Stock and flow diagram of the renewable energy development.

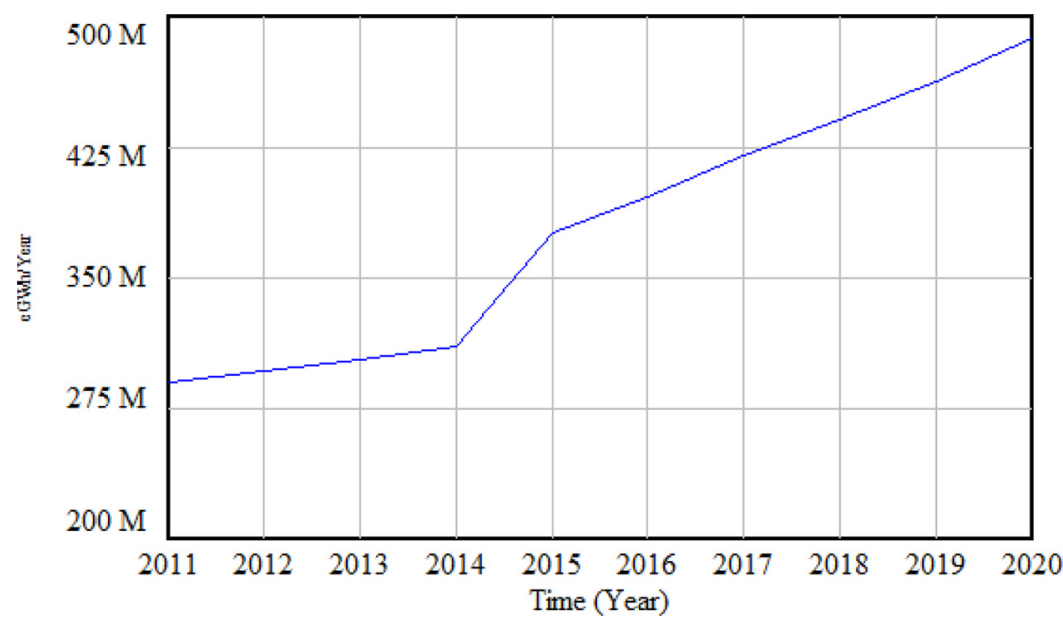

FIG. 8. Total Costs of electricity/heat generated by renewable energy resources $\left(\times 10^{6}\right.$ Euro).

According to the simulation, the total costs of electricity/heat generated by RERs during 2013 and 2020 will be around 302644000 and $487546000 €$ (61\% growth). As Figure 8 shows, a jump in costs increment will be occurred after 2014 that is related to the commercial development of hydropower plans (2014-2020) and solar and heat pumps (2018-2020).

Figures 9 and 10 show the total costs of RERs new instalations (investment costs) and O\&M costs (for existing systems and new installations).

The total amount of electricty/heat generated by RERs should reach to 77 TWh that means 9622 GWh new RE systems installation during 2011-2020. To evaluate the advantages or disadvantages of this amount of RE utilization, the total needed costs of heat/electricity generated by RERs is compared with total needed costs of electricity/gas generated by natural gas power plants (as the main source of fossil fuel for electricity generation in Finland). Figure 11 compares each three parts of the costs for RERs and natural gas. 


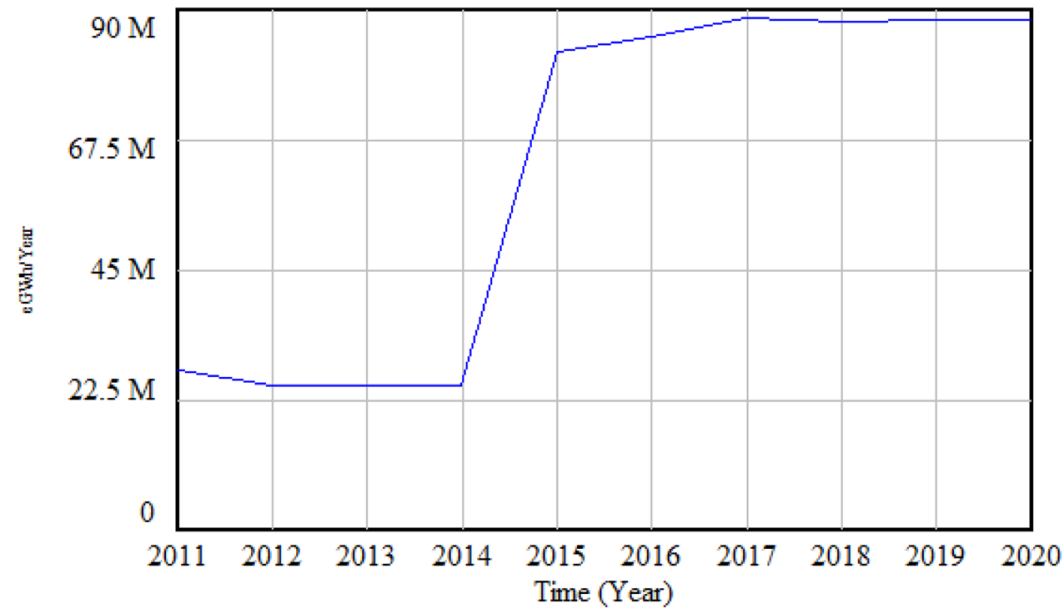

FIG. 9. Costs of new RE systems instalation $\left(\times 10^{6}\right.$ Euro $)$.

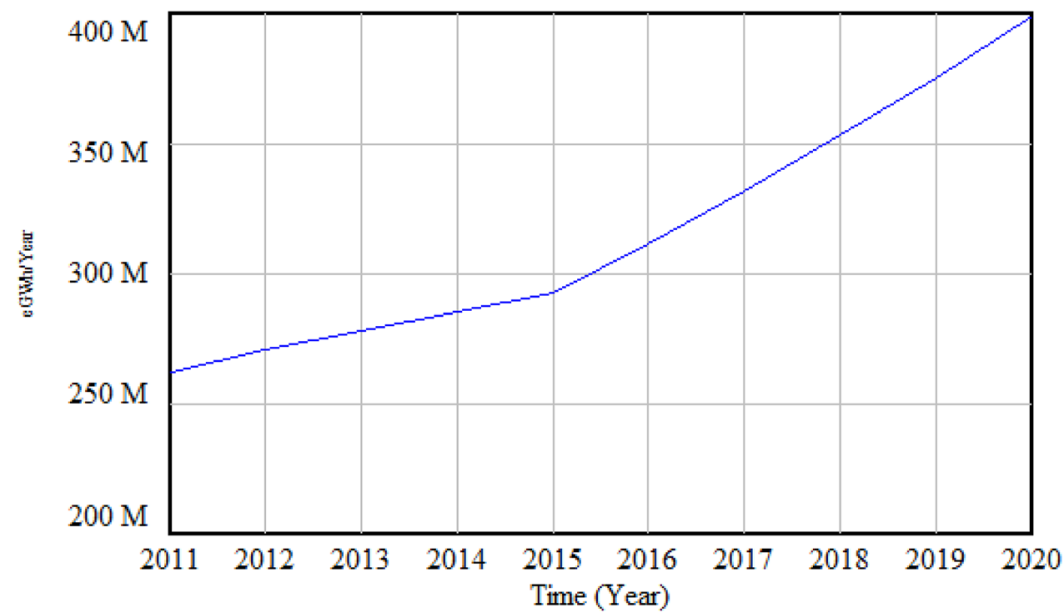

FIG. 10. O\&M costs of RE systems (new systems and under operation) $\left(\times 10^{6}\right.$ Euro).
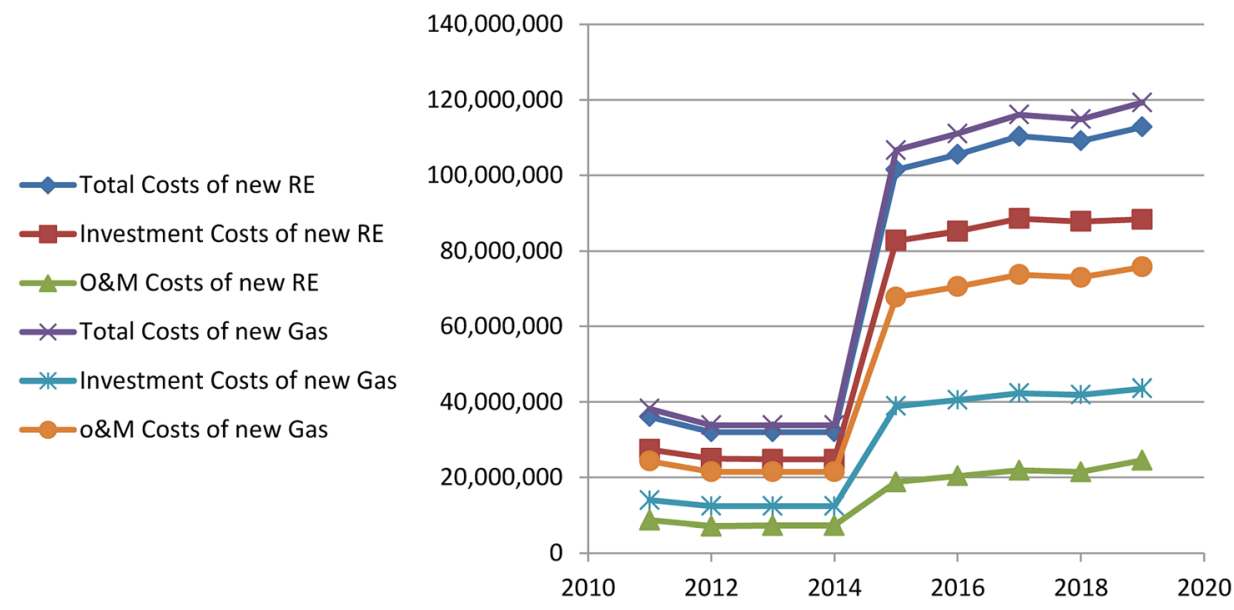

FIG. 11. Costs of new RE capacities compared to new natural gas power plants (Euro). 
As figure shows, the average O\&M costs of electricity generated by portfolios of RERs in Finland are almost $30 \%$ of the O\&M costs of natural gas during 2011-2020. Some factors such as gas prices (imports) and prices of $\mathrm{CO}_{2}$ emissions increase the O\&M costs of electricity generation by fossil fuels. On the other hand, the investment costs for new RE capacities are about 2 times of natural gas investment for the same amount of capacity. Overall, the total costs of new capacities, as well as O\&M costs of current RE systems bring 7\% saving compared to total costs of new natural gas power plants during 2011-2020 in Finland (without calculation in O\&M costs of current natural gas power plants). Therefore, due to $100 \%$ dependency of Finland on fossil fuels, long life cycle of RE technologies, and low O\&M costs of RE systems, development of RE utilization is highly recommended.

\section{VALIDATION AND TESTING OF THE MODEL}

Testing and validation of the models are very important in the system dynamics research. ${ }^{27}$ As Kelton and Law (1991) highlight, if a model has not a "valid" illustration of a system, the model results serve little useful information about the real system. Model testing and validation in the current research are based on the matching the models' results with the real system. To test and validate system dynamics models two approach was implemented: model structure validation, and model behavior validation. ${ }^{28}$

According to the "structure validation,"the structure of system dynamics model is suitable if it is internally consistent with its assumptions and the causal structures contains the keys feedback loops for describing the model and real system. The models implemented in the current research response to these factors from two viewpoints. First, our system dynamics model describes the behavior of the system based on the identified variables and causal loop extracted by the researchers' observations and expert's opinion. Second, it was designed based on the real data, trends, and opinions of the professionals in the energy sector. In particular, the researchers tried to involve stakeholders and decision makers of the policy options from the beginning of the model building. Therefore, changes in the simulation forecast closely follow changes in the real world systems.

From behavior validation aspect, our system dynamics model were checked by two methods: (1) Reviewing the process of the modeling and results and comparing with historical patterns and (2) testing the results and comparing with the plans defined by EU and government (e.g., share of the RE in electricity generation according to EU and Finland plans).

\section{CONCLUSION}

Concerns such as growing energy demands, limitations of fossil fuels, threats of carbon dioxide $\left(\mathrm{CO}_{2}\right)$ emission, and consequently global warming have caused policy makers and governments to debate about security of energy supply and role of diversification in their energy policies. Due to the high dependency of Finland on imported fossil fuels, renewable energy alternatives play an important role in the Finnish energy and climate strategies. However, commercial development of renewable energy systems is highly dependent to the utilization costs. This article discussed about a system dynamics model to evaluate and compare effect of renewable energy development plans on Finnish energy dependency during the period of 2011-2020. Due to the electricity consumption growth, as well as future of fossil fuels and related risks, renewable energy utilization is the best strategy to response to energy demand in Finland.

As future research, different scenarios such as implementation of new nuclear power plants for energy future can be defined to compare with renewable energy development in Finland. Indeed, the created system dynamics model can be implemented in other countries and the results can be compared with the current work. Further, accurate analysis of each parameters of renewable energy utilization, strategies for cost reduction along with other factors such as combination of energy market, tax, and regulatory incentives are subjects that are suggested by the authors for future. 
${ }^{1}$ A. Aslani, "Private sector investment in renewable energy utilization: Strategic analysis of stakeholder perspectives in developing countries," Int. J. Sustainable Energy (in press).

${ }^{2}$ Statistics Finland, Statistics, population on February 2013 (2013).

${ }^{3}$ A. Aslani, M. Naaranoja, and K. F. Wong, "Strategic analysis of diffusion of renewable energy in the Nordic countries," Renewable Sustainable Energy Rev. 22, 497-505 (2013).

${ }^{4}$ Statistics Finland, Energy supply and consumption, Statistical database, 2013.

${ }^{5}$ Ministry of Employment and the Economy Report (), Finland's national action plan for promoting energy from renewable sources pursuant to Directive 2009/28/EC, Energy Department, (2010).

${ }^{6}$ See http://www.motiva.fi/files/3475/Bioenergy_in_Finland.pdf for Bioenergy in Finland, 2011; accessed 16 December 2013.

${ }^{7}$ See http://www.eurelectric.org/media/26710/resap_nreap_report_-_final_8-11-11-2011-135-0001-01-e.pdf for National Renewable Energy Action Plans: An Industry Analysis, 2011, "EURELECTRIC Renewables Action Plan (RESAP)" EURELECTRIC; accessed 16 December 2013.

${ }^{8}$ A. Aslani, M. Naaranoja, P. Helo, E. Antila, and E. Hiltunen, "Energy diversification in Finland: Achievements and potential of renewable energy development," Int. J. Sustainable Energy 32(5), 504-514 (2013).

${ }^{9}$ A. Aslani, P. Helo, B. Feng, E. Antil, and E. Hiltunen, "Renewable energy supply chain in Ostrobothnia region and Vaasa city: Innovative framework," Renewable Sustainable Energy Rev. 23, 405-411 (2013).

${ }^{10}$ Ministry of Employment and the Economy Report (MEER), Finland's national action plan for promoting energy from renewable sources pursuant to Directive (Summery), Ministry of Employment and the Economy Report, Energy Department, 2010.

${ }^{11}$ A. Aslani, P. Helo, and M. Naaranoja, "Systematic analysis of renewable energy development in Finland," Appl. Energy (to be published).

${ }^{12} \mathrm{~A}$. Aslani, M. Naaranoja, and B. Zakeri, "The prime criteria for private sector participation in renewable energy investment in the Middle East (case study: Iran)," Renewable Sustainable Energy Rev. 16(4) 1977-1987 (2012).

${ }^{13} \mathrm{H}$. Holttinen, Production statistics of wind power, Annual report 2006 (VTT working papers, Espoo, 2007).

${ }^{14}$ See http://www.mpoweruk.com/energy_efficiency.htm for Electropaedia, Energy Efficiency (2013), accessed 16 December.

${ }^{15}$ EIA, See http://www.eia.gov/forecasts/aeo/pdf/0383(2012).pdf for The U.S. Energy Information Administration Annual Energy Outlook (2012), accessed 16 December 2013.

${ }^{16}$ W. Moomaw, P. Burgherr, G. Heath, M. Lenzen, J. Nyboer, and A. Verbruggen, “Annex II: Methodology,” In IPCC Special Report on Renewable Energy Sources and Climate Change Mitigation (2011).

${ }^{17} \mathrm{~T}$. Risto and K. Aija, Comparison of electricity generation costs, Research report EN A-56, Department of Energy and Environmental Technology, Lappeenranta University of Technology (2008).

${ }^{18}$ National Renewable Energy Laboratory (NREL), National PV cost values, for: NARUC 7-member consortium for PV resource characterization (2009).

${ }^{19}$ K. Branker, M. J. M. Pathak, and J. M. Pearce, “A review of solar photovoltaic levelized cost of electricity," Renewable Sustainable Energy Rev. 15(9), 4470-4482 (2011).

${ }^{20}$ I. T. Kukkonen, Geothermal Energy in Finland (World Geothermal Congress, Japan, 2000).

${ }^{21}$ A. Aslani, E. Antila, and K. F. Wong, "Comparative analysis of energy security in the nordic countries: The role of renewable energy resources in diversification,” J. Renewable Sustainable Energy 4(6), 062701 (2012).

${ }^{22}$ M. J. Radzicki and R. A. Taylor, "Origin of system dynamics: Jay W. Forrester and the History of System Dynamics," U.S. Department of Energy's Introduction to System Dynamics; retrieved 23, 2008

${ }^{23}$ J. D. Sterman, Business Dynamics: Systems Thinking and Modeling for a Complex World (McGraw Hill, 2000).

${ }^{24}$ J. D. D. Morecroft, "A critical review of diagraming tools for conceptualizing feedback system models," Dynamica part 1 8, 20-29 (1982).

${ }^{25}$ A. Aslani and K.-F. V. Wong, "Analysis of renewable energy development to power generation in the United States," Renewable Energy 63, 153-161 (2014).

${ }^{26}$ OECD Green Growth Studies Linking Renewable Energy to Rural Development, 2012.

${ }^{27}$ I. Moffatt, Causal and Simulation Modelling Using System Dynamics (North Australia Research Unit, Australia, 1992).

${ }^{28}$ E. P. Muliadiredja, "Indonesian energy policy pathways: From past trends to future alternatives," Ph.D. thesis, Massey University, New Zealand, 2005.

${ }^{29} \mathrm{IEA}$, see http://www.iea.org/statistics/statisticssearch/report/?\&country=ICELAND\&year=2011\&product=Balances for Energy Balance for countries (2011), accessed 16 December 2013.

${ }^{30}$ IEO, see http://www.eia.gov/forecasts/ieo/electricity.cfm for International Energy Outlook 2013 (EIA-US Department of Energy, 2013), accessed 16 December 2013.

${ }^{31}$ Annual Energy Outlook, Levelized Cost of New Generation Resources in the Annual Energy Outlook 2013, Report of the US Energy Information Administration (EIA) of the U.S. Department of Energy (2013).

${ }^{32}$ IEA-Sankey, see http://www.iea.org/Sankey/index.html\#?c=Finland\&s=Balance for Finland Balance in 2011 (2011). 